\title{
Contextual indicators in adult literacy studies: The case of PIAAC
}

Citation for published version (APA):

Allen, J. P., \& van der Velden, R. K. W. (2014). Contextual indicators in adult literacy studies: The case of PIAAC. In L. Rutkowski, M. V. Davier, \& D. Rutkowski (Eds.), Handbook of international large-scale assessment (Book 13 ed., pp. 345-360). CRC Press. Chapman \& Hall/CRC Statistics in the Social and Behavioral Sciences

Document status and date:

Published: 01/01/2014

Document Version:

Publisher's PDF, also known as Version of record

\section{Please check the document version of this publication:}

- A submitted manuscript is the version of the article upon submission and before peer-review. There can be important differences between the submitted version and the official published version of record.

People interested in the research are advised to contact the author for the final version of the publication, or visit the DOI to the publisher's website.

- The final author version and the galley proof are versions of the publication after peer review.

- The final published version features the final layout of the paper including the volume, issue and page numbers.

Link to publication

\footnotetext{
General rights rights.

- You may freely distribute the URL identifying the publication in the public portal. please follow below link for the End User Agreement:

www.umlib.nl/taverne-license

Take down policy

If you believe that this document breaches copyright please contact us at:

repository@maastrichtuniversity.nl

providing details and we will investigate your claim.
}

Copyright and moral rights for the publications made accessible in the public portal are retained by the authors and/or other copyright owners and it is a condition of accessing publications that users recognise and abide by the legal requirements associated with these

- Users may download and print one copy of any publication from the public portal for the purpose of private study or research.

- You may not further distribute the material or use it for any profit-making activity or commercial gain

If the publication is distributed under the terms of Article $25 \mathrm{fa}$ of the Dutch Copyright Act, indicated by the "Taverne" license above, 


\title{
Contextual Indicators in Adult Literacy Studies: The Case of PIAAC
}

\author{
Jim Allen \\ Maastricht University \\ Rolf van der Velden \\ Maastricht University
}

\section{CONTENTS}

What Is the PIAAC Project About?........................................................................345

Need to Monitor Human Capital..................................................................345

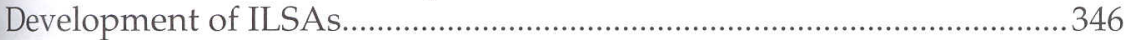

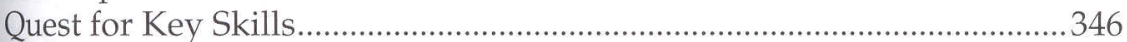

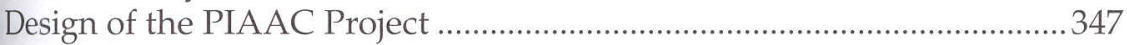

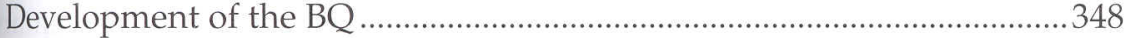

What Are the Policy Questions That PIAAC Seeks to Answer? ...................350

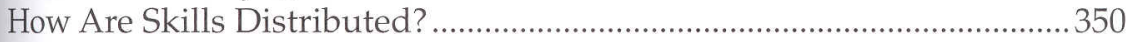

Why Are Skills Important?..................................................................... 351

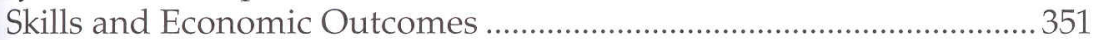

Skills and Other Outcomes ................................................................... 353

What Factors Are Related to Skill Acquisition and Decline? ................... 354

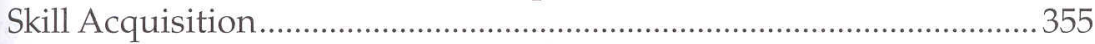

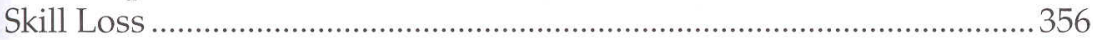

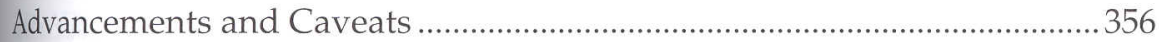

No Claims for Causality ............................................................................. 357

Underestimation of Specific Professional Skills........................................358

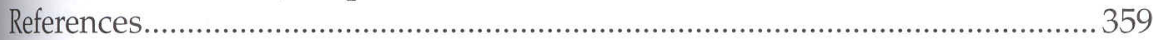

\section{What Is the PIAAC Project About?}

\section{Need to Monitor Human Capital}

The last few decades have seen an increased awareness of human capital as one of the driving forces of economic development. Policymakers are beginning to realize the importance of monitoring, and if necessary 
investing in, education and training as a way of improving the existing stock of skills. During the 1980s, the Organisation for Economic Co-operation and Development (OECD) started the large-scale project Indicators of Education Systems (INES) to measure input, process, and output of education (OECD 1994). This project resulted in the annual publication Education at a Glance. What soon became clear is that education and training as such are only weak indicators of human capital. Countries that have comparable levels of education can nevertheless differ significantly in the level of skills that affect important economic and social outcomes.

\section{Development of ILSAs}

This awareness triggered the development of several international largescale assessments (ILSAs), such as the Programme for International Student Assessment (PISA) aimed at students in secondary education, as well as surveys aimed at measuring the skills of adults: the International Adult Literacy Survey (IALS) carried out in 1994/1998 (OECD/Statistics Canada 2000) and the Adult Literacy and Life Skills Survey (ALL) carried out in 2003/2008 (OECD/Statistics Canada 2005). The Programme for the International Assessment of Adult Competencies (PIAAC) is the successor of these two adult literacy surveys. The survey aims at assessing key skills of the 16-65-year-olds. PIAAC is conducted by a group of 24 countries together with an international consortium consisting of several organizations (CapStan-Belgium; CRP-Luxembourg; DIPF-Germany; ETS-USA; GESIS—Germany; Maastricht University-the Netherlands; WESTAT-USA) working for OECD.

\section{Quest for Key Skills}

A major project supporting the above-mentioned ILSAs was the Definition and Selection of Competencies (DeSeCo) project, which was initiated by the OECD to provide an overarching framework for international skills assessments. Competencies are defined in this project as "the ability to successfully meet complex demands in a particular context through the mobilization of psychosocial prerequisites (including both cognitive and non-cognitive aspects)" (Rychen and Salganik 2003, p. 43).

The theoretical framework provided by the DeSeCo project indicates the main underlying competencies that give skills their significance, but does not in itself directly give rise to clear recommendations as to the skills to be measured. Binkley et al. (2003) developed a framework that provides more detailed guidance for the development of skills measurements for adults. This work concentrated on two strands of research: the skills necessary in the workplace and cognitive functioning. The choice of direct assessments in the ALL survey was based partly on these theoretical notions, but also on practical considerations, such as an established 
tradition of measurements that are sufficiently short to be used during a household survey (Murray 2003). As a consequence, ALL focused on literacy and numeracy skills. PIAAC builds on the direct assessments used in ALL, extending these to the area of problem solving in technology-rich environments (OECD 2012).

In the adult literacy surveys the skills of the population are not only measured directly in the assessment, but also indirectly in the background questionnaire (BQ) by asking about the use of these skills both inside and outside working life. This engagement or use of skills is of course strongly correlated with the actual performance, but it also allows examining whether there are skill mismatches (e.g., people who have good reading skills, but do not use them in working life).

Other skill areas, particularly those involving intrapersonal, interpersonal, and other generic "soft" skills, are not included in the direct assessment, but the $\mathrm{BQ}$ does contain several indicators related to skill use or skill requirements in these areas. This comprises a module that has been specifically developed for the PIAAC project: the Job Requirements Approach (JRA) Module (Green 2008). The main arguments for developing a separate JRA module for PIAAC were the following:

- To provide a cost-effective way of assessing the relevance of skills not covered by the direct assessments

- To provide some information on the demand side for skills, in order to supplement the information provided by the direct assessments on the supply side

The JRA module comprises questions on problem solving, a range of interaction/social skills (influence, managerial skills, communication skills), and physical skills (strength and manual skill).

\section{Design of the PIAAC Project}

The PIAAC project is currently carried out in $23 \mathrm{OECD}$ and 2 partner countries. In each country, some 5000 adults were surveyed in 2011/2012 and results are expected in 2013. A second round with an additional eight countries has recently started and will finish in 2015.

Like PISA, PIAAC is designed as multicycle research. New waves are expected to start every 5-7 years. Moreover, the tests and questionnaires are designed such that the main results can also be compared with the earlier IALS and ALL surveys. This means that PIAAC will not only allow for comparisons across countries, but also for comparisons over time. This is important, as many of the policy-relevant issues deal with evaluations of changes in the educational or labor market policy. The OECD intends to have a complementary policy survey to document relevant policy initiatives that might affect the skills of the population (Schleicher 2008). This allows for the 
identification of differences in policies across countries that might serve as an explanation for observed skill differences.

Although PIAAC is designed as a cross-sectional survey, there are a couple of longitudinal elements as well. The multicycle nature and the earlier adult surveys allow for so-called synthetic cohort constructions (see, e.g., Green and Riddell 2012; Willms and Murray 2007). Basically, this approach "follows" a certain age cohort over time: for example, the 30-40-year-olds in the IALS study of 1994 are compared with the 39-49-year-olds in the ALL study of 2003. In some countries, the PIAAC project intends to adopt a specific form of a longitudinal study by linking the individual data to registry data. This will be done in those countries where such national registries are available; the Scandinavian countries and the Netherlands are examples. These national registries contain information on, for example, labor force participation, occupation, earnings, educational attainment, and social security. This will enable the researchers to link the PIAAC data to later outcomes in life and thus construct a longitudinal design.

\section{Development of the $B Q$}

The initial developmental work for PIAAC was undertaken by the OECD as early as 2006. Several working groups from Network B of the OECD were involved in developing parts of the questionnaire. A separate pilot was set up to develop the JRA module. This module was based on the U.K. Skills Survey (Felstead et al. 2002) and tested in four different countries in 2008 (Green 2008). Based on the results of the developmental work, the OECD set up a country consulting process to make a priority rating of what should be covered in the BQ for PIAAC.

This early developmental work and priority rating formed the input of the development of the $\mathrm{BQ}$ by the PIAAC Consortium* that was responsible for the actual PIAAC project. The consortium was assisted by a group of experts who advised on the content of the questionnaire. Several drafts of the BQ were developed and discussed with the countries. Finally, a questionnaire with a total length of some 55 min was tested in a field test carried out in spring 2010. Based on the results of this field test and a country priority rating concerning the policy relevance of the different items, a final version was developed for the main survey with a total length of 40-45 min.

Table 16.1 presents an overview of the variables collected in the BQ. These can basically be distinguished into variables that are needed to perform an adequate descriptive analysis of the distribution of skills in the population, variables that can be seen as an important determinant of skills development, variables that are related to the outcomes of skills, and variables that

\footnotetext{
* This consortium was led by ETS and consisted of the following organisations: cApStAn, DIPF, ETS, GESIS, IEA, ROA, TUDOR, and WESTAT. ROA was responsible for the development of the $B Q$.
} 


\section{TABLE 16.1}

Overview of Variables

\begin{tabular}{lcccc}
\hline Concept & $\begin{array}{c}\text { Descriptive } \\
\text { Analysis }\end{array}$ & $\begin{array}{c}\text { Determinants } \\
\text { of Skills }\end{array}$ & $\begin{array}{c}\text { Economic and } \\
\text { Social Outcomes }\end{array}$ & $\begin{array}{c}\text { Control } \\
\text { Variables }\end{array}$ \\
\hline
\end{tabular}

Direct assessment literacy, numeracy, problem

solving

Skill use literacy,

numeracy, ICT

Skill use in other

domains (JRA)

Gender

(Reporting category)

(Reporting category)

Age

(Reporting category)

Education parents

(Reporting

category)

Cultural capital parental

home

Mother tongue

Language spoken at home

Learning style

Region

(Reporting

category)

Highest level of education

(Reporting

category)

Qualifications not

completed

Field of study

Current/recent training

Employers' contribution

to training costs

Training undertaken in

working time

Reasons for training

(work-related versus

non-work-related)

Work experience (total

duration, changes of

employer)

On-the-job training

Informal learning at work

Current main status

(labour force status and

self-declared status)

(Reporting

category) 


\section{TABLE 16.1 (continued)}

Overview of Variables

\begin{tabular}{|c|c|c|c|c|}
\hline Concept & $\begin{array}{c}\text { Descriptive } \\
\text { Analysis }\end{array}$ & $\begin{array}{l}\text { Determinants } \\
\text { of Skills }\end{array}$ & $\begin{array}{l}\text { Economic and } \\
\text { Social Outcomes }\end{array}$ & $\begin{array}{c}\text { Control } \\
\text { Variables }\end{array}$ \\
\hline Occupation & $\begin{array}{c}\text { (Reporting } \\
\text { category) }\end{array}$ & & & \\
\hline Economic sector & $\begin{array}{r}\text { (Reporting } \\
\text { category) }\end{array}$ & & & \\
\hline \multicolumn{5}{|l|}{$\begin{array}{l}\text { Employed versus } \\
\text { self-employed }\end{array}$} \\
\hline \multicolumn{5}{|l|}{ Supervisory status } \\
\hline \multicolumn{5}{|l|}{ Tenure current job } \\
\hline Firm size & $\begin{array}{c}\text { (Reporting } \\
\text { category) }\end{array}$ & & & \\
\hline \multicolumn{5}{|l|}{ Job security } \\
\hline \multicolumn{5}{|l|}{ Working hours } \\
\hline \multicolumn{5}{|l|}{ Earnings } \\
\hline \multicolumn{5}{|l|}{ Education-job match } \\
\hline \multicolumn{5}{|l|}{ General health status } \\
\hline \multicolumn{5}{|l|}{ Voluntary work } \\
\hline \multicolumn{5}{|l|}{ Political efficacy } \\
\hline Social trust & & & & \\
\hline
\end{tabular}

are needed as control variables. We will describe these variables and their purpose more specifically in the next section.

\section{What Are the Policy Questions That PIAAC Seeks to Answer?}

The PIAAC project focuses on three broad policy questions:

1. How are skills distributed?

2. Why are skills important?

3. What factors are related to skill acquisition and decline?

We will elaborate on how PIAAC addresses these questions in more detail in the following subsections. Note that the three questions follow the same logic as displayed in Table 16.1.

\section{How Are Skills Distributed?}

Human capital is considered as the driving force of economic growth. Investments in skills are essential in order to keep up with technological 
change (so-called skill-biased technological change: Levy 2010), as well as with other changes as a result of market trends or organizational developments (e.g., the introduction of high-performance workplace practices: OECD 1999). Policymakers have an interest in monitoring the stock of human capital in their country and in identifying the different levels among relevant subgroups. PIAAC assesses the stock of human capital in a society by providing a descriptive analysis of the distribution of skills proficiencies and skills use in the adult population. The survey will enable countries to answer questions such as

- How are skills proficiencies distributed across countries, or across regions, occupations, or sectors of industry within countries?

- Are skills equally distributed among relevant subgroups based on gender, age group, or migration status?

- Are skills being underdeveloped for particular levels of education?

- What is the level of investment in education and training, and are particular population subgroups excluded from adult learning systems?

In order to answer these questions, the survey assesses the level of skill proficiency in the three different domains (literacy, numeracy, and problemsolving in technology-rich environments), the degree of use of these skills both at work and in everyday life, as well as the degree of use of skills at work in other domains (the JRA module). The BQ also contains several indicators of investments in education and training, such as the level and field of the highest degree attained in education, the volume and intensity of formal and nonformal training received in the past 12 months, the extent to which this training has taken place for work-related reasons, who is financing such investments, and reasons for not participating in further training.

In order to effectively address questions concerning the distribution of skills across relevant subgroups, the $\mathrm{BQ}$ contains questions that allow us to derive relevant reporting categories, such as those based on gender, age, socioeconomic background, migration status, labor market status, region, occupation, industry sector, firm size, and level of education.

\section{Why Are Skills Important?}

\section{Skills and Economic Outcomes}

Policymakers would have little interest in investments in skills if skills showed no relation with relevant economic and social outcomes. Other services compete with education and training for a share in budgets, so the case for returns to educational investments needs to be based on a secure and sophisticated evidence base. Moreover, governments and the public have a legitimate desire to hold education accountable for the effects of the efforts put into this sector. For that reason, one of the key goals of the $B Q$ is 
to provide indicators that can be used to show whether differences in skill levels matter, economically and socially. Figure 16.1 shows the underlying mechanisms how skills are thought to affect these outcomes.

The most obvious concern is to establish that skill levels are related to economic outcomes of individuals. Cognitive skills are thought to be a key determinant of individuals' productivity, so it is not surprising to find that cognitive skills are related to economic success. There is a large body of evidence showing that higher cognitive skills are indeed associated with better labor market outcomes (e.g., Heckman et al. 2006). Relevant questions to be addressed are

- How are skills related to individual employment opportunities, job security, earnings, or other indicators of labor market success?

- Do low skill proficiencies form a barrier to individuals entering the labor force?

- Is there a minimum level of skills that is needed to be employable?

- Can skills compensate for low educational qualifications?

One of the interesting questions in this respect is the precise role of education and skills in producing these outcomes. There are rivaling hypotheses on this point. The human capital theory (Becker 1964) claims that people with more years of schooling earn more because they are more productive. Scholars such as Spence (1973) and Arrow (1973) have pointed out that rewards are

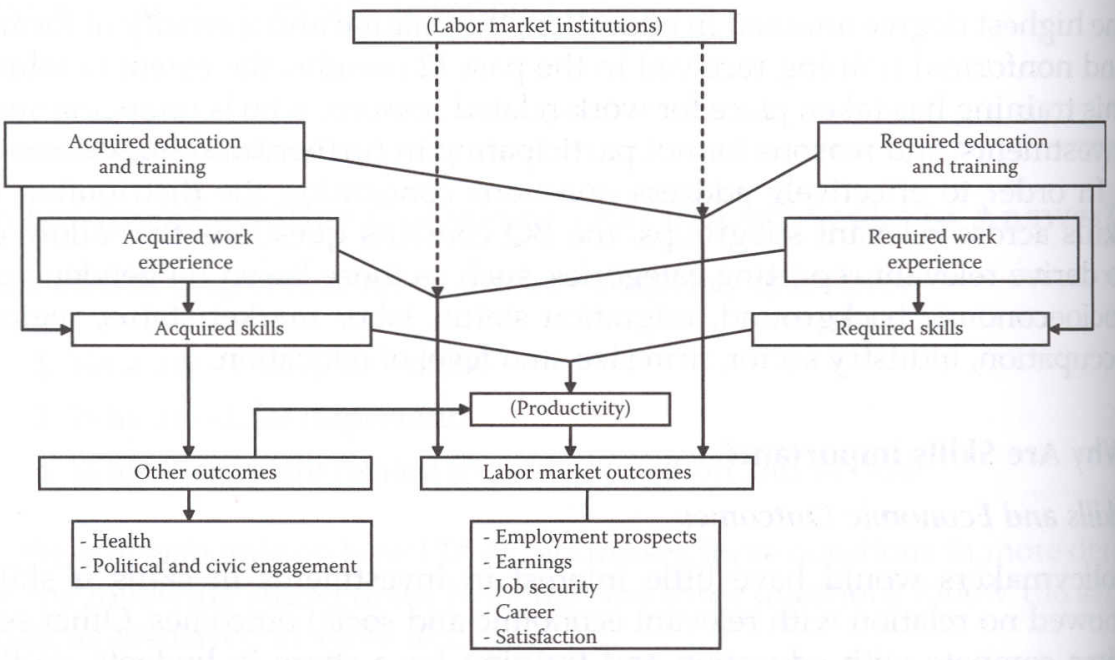

FIGURE 16.1

Schematic representation of economic and social outcomes (variables in brackets () not measured). 
often based on signals such as formal qualifications as well as on the basis of productivity. The labor queue theory (Thurow 1975) points out that many relevant skills are learned on the job rather than in education. Credentialists such as Collins (1979) claim that more education does not lead to superior skills at all, but is used by "gatekeepers" to legitimize the rationing of access to high-status, highly paid jobs. There is probably an element of truth in all these theories; the crucial point is to specify the contexts under which one or the other mechanism prevails. In a study like PIAAC, we might expect large differences between countries and between sectors of industry in the relative effect of skills versus educational credentials on labor market outcomes.

Key economic outcome indicators included in the BQ are current labor market status (employed, unemployed, inactive), self-declared main status (allowing a better understanding of the situation of those not in the labor force), working hours, individual earnings, job security, occupational status, and the quality of the match between education and work.

\section{Skills and Other Outcomes}

Apart from economic outcomes, the relation of skills with other outcomes, such as health status and civic participation, is of interest as well (Schuller and Desjardins 2007). Adverse outcomes in such areas place large burdens on governments, businesses, and individuals, both in terms of direct expenditures (such as public health care budgets) and indirect costs (such as productivity loss due to worker illnesses). Relevant questions are

- To what extent is literacy related to the health status of individuals?

- To what extent do individuals with low skills appear to be less engaged in broader society (voluntary work, social trust)?

- To what extent does the engagement of migration groups or linguistic minorities appear to be inhibited by their lack of skill in the main language(s) in their country of residence?

Education not only affects individual outcomes in these domains, but also social returns due to spillover effects. As with the effects of education on labor market outcomes, the effects of education on other outcomes are still not fully understood. Broadly, two mechanisms can be distinguished (Pallas 2000): an effect on skills-education directly affects knowledge and skills that are relevant for healthy behavior, civic engagement, and so on-and an effect on allocation-higher education increases the chance of ending up in healthier jobs or in social networks in which civic engagement is higher. The PIAAC data should provide clues as to the extent to which of these mechanisms is dominant, and how this varies both between and within countries.

The BQ includes indicators of subjective health status, involvement in voluntary work, political efficacy, and social trust. 


\section{What Factors Are Related to Skill Acquisition and Decline?}

Assuming that skills matter economically and socially, policymakers have an interest in knowing what factors are related to the acquisition but also to the decline of skills over the life course. Figure 16.2 shows the assumed interplay of the main determinants of skill acquisition and decline.

The primary interest is in factors that can be directly influenced by policy, such as the provision of education and training. However, it is also relevant to compare the efficiency of such skill production routes with that of other routes not directly under the control of policymakers, such as informal learning activities in which people may engage at work or outside of work. Assessing the overall relation between education and training and skill levels is only a first step in unraveling the determinants of skills acquisition. We can assume that not all education and training activities have the same impact on skills development. Nor can we assume that the impact is the same for all relevant subgroups. Policymakers have an interest in seeing which characteristics of education and training are most strongly related to higher skill levels in the population and which subgroups appear to gain most from which type of intervention. Finally, we need to be aware that skills cannot only be acquired, but skills can also be lost. Preventing skill decline is probably just as important as promoting skill acquisition, but the underlying factors affecting these processes may be quite different, and it is important to have good insight into both processes. This means that the survey needs to

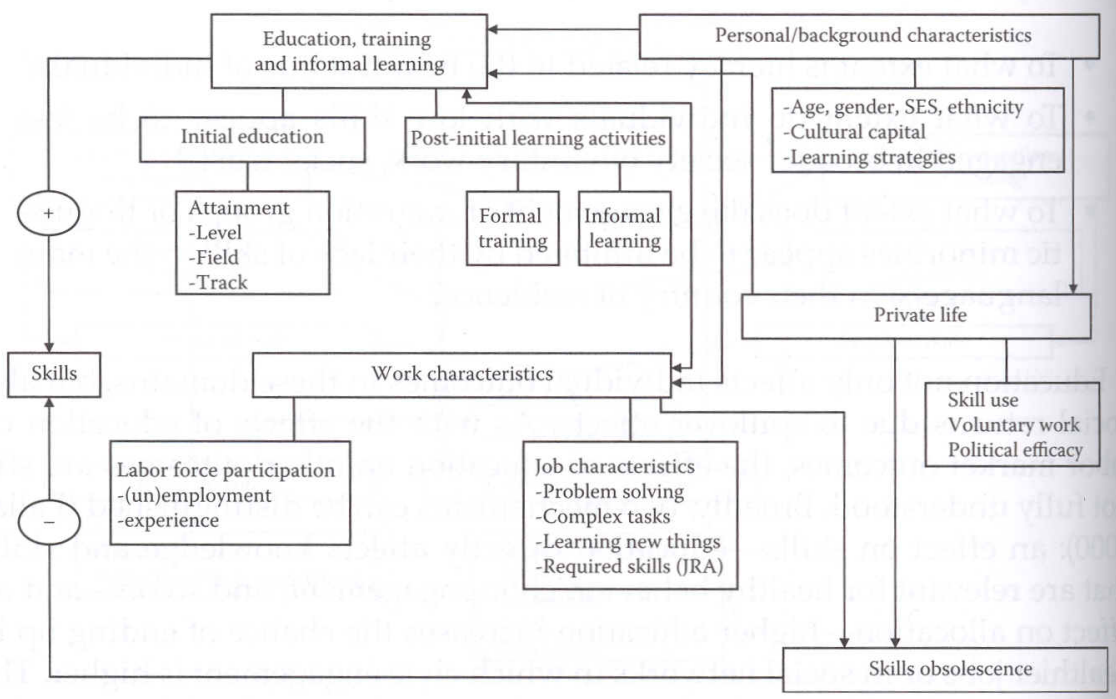

FIGURE 16.2

Schematic representation of skill acquisition and decline. 
enable countries to answer questions such as

- What is the relation between education, training, and other learning activities (such as informal on-the-job learning) and the skill development of people?

- Are there subgroups that appear to profit more or less from investments in education and training?

- What is the relation between underinvestment in work-related training and adult skill levels?

- How are characteristics of the work environment related to skill levels?

- Is informal learning on the job a substitute for work-related training?

- How do processes of skill acquisition and decline vary with age?

- What are the factors that are related to skill decline?

- Are these the same as the factors that are related to skill acquisition?

\section{Skill Acquisition}

There is little doubt that education is the single most important factor that contributes to the acquisition of skills. However, people do not only learn during initial education, but also later in life. Several studies have found high returns to workers' participation in training (for a review, see Bassanini et al. 2005), but others have questioned whether it is formal training that really makes the difference. Employees spend much more time on informal learning activities than on formal learning, and the activities are often interrelated (Borghans et al. 2006). We have already indicated that the BQ contains several indicators related to the formal and informal training in which adults have been engaged, like the level and field of the highest degree that was attained in education, and the volume and intensity of the formal and informal training in the past 12 months. The $\mathrm{BQ}$ also explores other routes through which skills can be acquired, such as informal learning on the job.

Regardless of the specifics of the training and learning practices available through the organization in which individuals work, the amount of work experience acquired can be expected to have a strong effect on skills development. However, one is most likely to be exposed to learning situations early in one's career. As the career develops, the chance that one will be exposed to new stimuli is decreased, a pattern that is reinforced by typical patterns of brain development over the life cycle. In addition to total work experience, the number of changes of employer and/or career breaks is therefore also important. The PIAAC BQ contains items on each of these factors.

There are also factors outside the world of work that can affect development and retention of competencies. The questionnaire therefore covers 
some activities in which respondents may be involved in in everyday life from which they can learn as well.

Not everybody is equally likely to profit from investments in these forms of learning. Some groups may face constraints in their investments, or some may have an inappropriate learning style that prevents optimal development of their skills in education or training. The BQ contains indicators of constraints that are expected to affect the differential investment in education and training, which may be related to gender, marital status, family formation, socioeconomic status, and ethnic status. Moreover, the $\mathrm{BQ}$ contains a scale that measures the kind of learning strategy that adults apply when learning something new.

\section{Skill Loss}

The single most important finding of the IALS and ALL surveys was that skill loss was sufficient to offset all expected gains from increasing educational quality and quantity. Higher-order brain functions follow a predictable developmental pattern, and reach a plateau of optimal functioning in young adulthood. Most cognitive abilities tend to decline with advancing age. However, large individual differences exist in the onset and rate of decline of specific cognitive functions. Fluid abilities (functions that involve controlled and effortful processing of novel information) typically start declining in the mid-20s, while crystallized skills (the representation of learned skills and access to knowledge) may improve until and even beyond the age of 60 . One may hypothesize that numeracy and literacy skills relate more strongly to crystallized abilities, and are therefore less susceptible to decline than dynamic problem solving in a technology-rich environment, which may relate more to fluid abilities.

Building partly on insights from cognitive and neuropsychology, De Grip and Van Loo (2002) developed a typology of different types of skills obsolescence, of which so-called skill wear — which results from the natural aging process and may be accelerated by physically or mentally challenging working conditions - and skill atrophy - which is due to the lack or insufficient use of skills and may be brought on by unemployment, career interruptions, or working below one's level of education-are particularly relevant from the point of view of PIAAC. The BQ contains indicators that are thought to be related to wear (age, health) and atrophy (unemployment, working below one's level, tenure, and sector of industry). In addition, several of the abovementioned indicators of workplace learning have a direct bearing on not only the job learning but also the risk of skills obsolescence in the form of atrophy.

\section{Advancements and Caveats}

Without any doubt, the PIAAC will become one of the most important ILSAs of the coming decade. Part of its strength lies in the innovative character of 
the assessment, that is, the development of the new domain of problem solving in technology-rich environments, as well as the development of the JRA module to assess a broad array of skills used at work. The strength also lies in the coherence of the conceptual framework underlying both the direct assessment and the $\mathrm{BQ}$. The survey is also innovative in using a specifically developed computer platform that allows for both the $\mathrm{BQ}$ and the direct assessment to take place on the computer (only respondents who lack the necessary computer skills will take a paper-and-pencil test).

Compared to many international comparative surveys, PIAAC is also rather unique in terms of the ex-ante harmonization of the instruments. All items were centrally determined and national adaptations needed to be approved by the consortium. In addition, the translations were checked by the consortium to ensure the overall comparability of the items. The use of a computer platform also greatly improved the quality of the data and kept nonresponse to a minimum.

Despite these advancements made in PIAAC, there are some caveats that we would like to point out.

\section{No Claims for Causality}

For evidence-based policy, it is important that the estimates of the relationships between various factors and skills are as free as possible from bias. Policymakers would be misinformed if the effects of, for example, investments in education or training were seriously overestimated (in which case some of the investment might be a waste of money) or underestimated (in which case policymakers might decide to withhold investments in education or training that would have yielded large returns in terms of skills). Estimates based on nonexperimental data collections such as the ones obtained through PIAAC may be biased. The problem occurs when there is some other variable that affects both the decision of an individual to invest in education or training (the variable of interest) as well as his or her skills levels (the dependent variable). When this variable is not controlled for in the analysis (unobserved heterogeneity), the parameter estimates of the other variables in the model may be biased: the so-called omitted variable bias. Another problem occurs when the direction of causality is not clear (endogeneity). For example, people may follow training because they were promoted to a better job rather than having been promoted as a result of their investment in training. In that case, the causal link between training and wages is reversed.

This is not a new problem, and in the past social scientists have used panel designs and control variables to obtain better estimates of the statistical associations of interest. However, this will never rule out the possibility that some omitted variable may bias the true relation. In the past decade, new statistical techniques have been developed to deal with this problem of unobserved heterogeneity, such as the use of instrumental variables or the use of selection models (e.g., Heckman 1979). The basic idea is to use other variables or 
other models to estimate the "true" effect of the variables of interest. It is now a common understanding among social scientists that the use of these additional techniques are essential to improving our knowledge of the effects of the variables of interest, and to giving policymakers the unbiased estimates they need to make valid decisions.

For the PIAAC project, we have tried to develop instrumental variables that could be used in analyses. This is not an easy task, but we did come up with some instruments that could be used, for example, birth order, proximity of potential schooling institutes or discount rate to instrument education, and organizational restructuring and distance to current and alternative jobs to instrument non-formal training. The main goal of including such instrumental variables is to get an unbiased estimate of the effect of, say, education on skills. These variables should therefore be truly exogenous in the sense that they are unrelated to the dependent variable (skills levels) or to other unobserved explanatory variables. By their very nature, these variables usually have little policy relevance in themselves. That was one of the main reasons why most of the instrumental variables that were proposed were not included in the final questionnaire for the field test. In the face of severe space limitations, it was hard to justify retaining variables that have little policy relevance in themselves, even if they could have helped in obtaining the unbiased estimates that policymakers need to make evidence-based policy.

\section{Underestimation of Specific Professional Skills}

Despite the fact that employers often list generic cognitive skills and personal traits as the most important skills required in the workplace, professional expertise is a conditio sine qua non for success in many occupations. For example, nobody would doubt that in order to become a good medical doctor, architect, or car mechanic, one needs to acquire the domain-specific knowledge and skills that make up the professional domains of these occupations. The German psychologist Weinert formulated this as follows: "Over the last decades, the cognitive sciences have convincingly demonstrated that context-specific skills and knowledge play a crucial role in solving difficult tasks. Generally, key competencies cannot adequately compensate for a lack of content-specific competencies" (Weinert 2001, p. 53).

There is, however, a plethora of specific professional skills, and usually they are not taken up in ILSAs such as PIAAC, simply because there is no common assessment instrument that allows all different types of professional skills to be measured in a meaningful way for large populations.* The absence of direct measures of specific professional skills will automatically lead to an overestimation of the relevance of the generic skills, such as the ones measured in the 
direct assessment. It underscores the importance of obtaining detailed information on the occupation of working respondents, as is done in the BQ. Since the differences among occupations in the skills measured in the direct assessments is likely to be at least matched and probably eclipsed by differences in level and type of specific skills, the residual occupation-level variance in economic outcomes should provide a rough indication of the economic importance of specific skills relative to the generic skills measured.

\section{References}

Arrow, K.J. 1973. Higher education as a filter. Journal of Political Economy, 2(3), 193-216. Baethge, M., F. Achtenhagen, L. Arends, E. Babic, V. Baethge-Kinsky, and S. Weber 2006. PISA-VET: A Feasibility-Study, Stuttgart: Frans Steiner Verlag.

Bassanini, A., A.L. Booth, G. Brunello, M. De Paola, and E. Leuven. 2005. Workplace Training in Europe. IZA-Discussion paper 1640, Bonn: IZA.

Becker, G.S. 1964. Human Capital: A Theoretical and Empirical Analysis with Special Reference to Education, New York: Columbia University Press.

Binkley, M.R., R. Sternberg, S. Jones, D. Nohara, T.S. Murray and Y. Clermont. 2003. Moving towards measurement: The overarching conceptual framework for the ALL study, In: T.S. Murray, Y. Clermont, and M. Binkley (eds.) Measuring Adult Literacy and Life Skills: New Frameworks for Assessment, Ottawa, Canada: Statcan. Borghans, L., B. Golsteyn, and A. de Grip. 2006. Meer Werken is Meer Leren: Determinanten van Kennisontwikkeling, 's-Hertogenbosch: CINOP.

Collins, R. 1979. The Credential Society: An Historical Sociology of Education and Stratification, New York: Academic Press.

De Grip, A. and J. Van Loo. 2002. The economics of skills obsolescence: A review, In: A. de Grip, J. van Loo, and K. Mayhew (Eds.), The Economics of Skills Obsolescence, Research in Labour Economics, vol. 21, Amsterdam/Boston: JAI Press, 1-26.

Felstead, A., D. Gallie, and F. Green. 2002. Work Skills in Britain 1986-2001, Oxford: SKOPE, Oxford and Warwick Universities.

Green, D.A. and W.C. Riddell. 2012. Ageing and Literacy Skills: Evidence from Canada,

Norway and the United States, IZA-Discussion Paper 6424, Bonn: IZA Bonn: IZA. Green, F. 2008. Draft Report on the Validation of the Results of the Job Requirements Approach (JRA) Pilot Survey. Mimeo.

Heckman, J.J. 1979. Sample selection bias as a specification error. Econometrica 47, 1, 153-161.

Heckman, J.J., J. Stixrud, and S. Urzua. 2006. The effects of cognitive and noncognitive abilities on labour market outcomes and social behavior. Journal of Labour Economics, 24(3), 411-482.

Levy, F. 2010. How Technology Changes Demands for Human Skills, OECD Education Working Papers 45, Paris: OECD.

Murray, T.S. 2003. Reflections on international competence assessments, In: D.S.

Rychen and L.H. Salganik (eds.), Key Competencies for a Successful Life and a Well-

Functioning Society, Göttingen: Hogrefe \& Huber, 135-159. 
OECD. 1994. Making Education Count: Developing and Using International Indicators, Paris: OECD.

OECD. 1999. Economic Outlook, Paris: OECD.

OECD/Statistics Canada. 2000. Literacy in the Information Age: Final Report of the International Adult Literacy Survey, Paris: OECD and Ottawa: Statistics Canada.

OECD/Statistics Canada. 2005. Learning a Living: First results of the Adult Literacy and Life Skills Survey, Paris: OECD and Ottawa: Statistics Canada.

OECD. 2012. Literacy, Numeracy and Problem Solving in Technology-Rich Environments: Framework for the OECD Survey of Adult Skills, Paris: OECD.

Pallas, A.M. 2000. The effects of schooling on individual lives. In: M.T. Hallinan (ed.), Handbook of the Sociology of Education, New York: Kluwer Academic/Plenum Publishers, 499-525.

Rychen, D.S. and L.H. Salganik. 2003. A holistic model of competence, In: D.S. Rychen and L.H. Salganik (eds.) Key Competencies for a Successful Life and a WellFunctioning Society, Göttingen: Hogrefe \& Huber, 41-62.

Schleicher, A. 2008. PIAAC: A new strategy for assessing adult competencies. International Review of Education, 54, 627-650.

Schuller, T. and R. Desjardins. 2007. Understanding the Social Outcomes of Learning, Paris: OECD.

Spence, M. 1973. Job market signalling, Quarterly Journal of Economics, 87, 1, 355-374. Thurow, L.C. 1975. Generating Inequality, New York: Basic Books.

Weinert, F.E. 2001. Concept of competence: A conceptual clarification, In: D.S. Rychen and L.H. Salganik (eds.), Defining and Selecting Key Competencies, Göttingen: Hogrefe \& Huber, 45-65.

Willms, J.D. and T.S. Murray. 2007. Gaining and Losing Literacy Skills Over the Lifecourse, Ottawa: Statistics Canada. 